\title{
HASLAM OF “BEDLAM”, KITCHINER OF THE “ORACLES": TWO DOCTORS UNDER MAD KING GEORGE III, AND THEIR FRIENDSHIP
}

by

\section{FRANCIS SCHILLER*}

IN the medical pantheon, section of psychiatry, John Haslam (1764-1844) occupies only a small niche. He is represented there under two headings: one flattering, the other discreditable. As a forerunner of attempts to correlate brain pathology with mental disease - general paresis of the insane, or paralytic dementia, in particular - he qualifies as a minor hero; as a callous practitioner of the institutional care for mental patients he emerges as a chastized minor villain. He has more recently been hailed as the first psychiatrist to recognize not only the simple dementing form of schizophrenia before Morel named it demence précoce (1850) and to describe the attendant feature of autism, but also to draw attention to obsessional neurosis and the cyclic nature of mania and melancholia. ${ }^{1}$ Leigh's Historical development of British psychiatry allots to Haslam one-fifth of the first volume. ${ }^{2}$

Failing to meet the emerging humanitarian standards of asylum reform, Haslam was, in 1816, at the age of fifty-two, dismissed from his post. Titled Apothecary, he had for twenty years assumed the duties of an assistant physician at the Royal Bethlem Hospital, the proverbial over five centuries-old lunatic asylum near London. Again, as to the bright side of his reputation, "the respectable testimony of $\mathrm{Mr}$ Haslam" was acclaimed by such a prominent contemporary physician as Thomas Beddoes; above all he was quoted by Pinel often and with respect. ${ }^{3}$ But when he died, eighty years old, his most fulsome obituary appeared, not in the Lancet where he received a few cold lines, ${ }^{4}$ but, surprisingly, in the London Literary Gazette and Journal of Belles Lettres, Arts, Sciences, etc. ${ }^{5}$ In part, it was copied by such divergent sources as the fashionable Gentleman's Magazine, also of London, on the one hand, the sober American Journal of Insanity, ${ }^{6}$ on the other. After giving his degrees such as they were - some acquired in middle age, i.e. following his dismissal from Bethlem

\footnotetext{
* Francis Schiller, MD, Clinical Professor of Neurology and Senior Lecturer, History of Health Sciences (Emeritus), University of California, San Francisco, California 94143, USA.

' G. M. Robertson, 'The discovery of general paralysis', J. ment. Sci., 1923, 69: 1-23. J. Zelmanovits, 'A historical note on the simple dementing form of schizophrenia', Proc. R. Soc. Med., 1953, 46: 931-933. G. E. Vaillant, 'John Haslam on early infantile autism', Am. J. Psychiat., 1962, 119: 376.

${ }^{2}$ D. Leigh, The historical development of British psychiatry, Oxford, Pergamon Press, 1961, vol. 1, pp. 94-147.

${ }^{3} \mathrm{R}$. Hunter and I. Macalpine, Three hundred years of psychiatry, 1535-1860. A history presented in selected English texts, London, Oxford University Press 1963, pp. 578-580, 632-639, 695-700.

Lancet, 1844, i: 571.

${ }^{3}$ Anon. [W. J. Jerdan?], 'Biography. Dr Haslam', Lond. Lit. Gaz., 27 July 1844, pp. 484-485.

- Am. J. Insanity, 1844, 1: 192, Gentleman's Mag., September 1844, pp. 322-323. (Preceded by Dr Heinroth's obituary.)
} 


\section{F. Schiller}

(MD Aberdeen; inscribed but not graduated from Pembroke College, Cambridge; Licentiate of the Royal College of Physicians, London) - and listing a dozen titles of his psychiatric publications, the Literary Gazette of 27 July 1844 duly went on to say that Dr Haslam was:

Long and justly celebrated as a physician in cases of insanity, and a man otherwise of great attainments, information, and literary tastes. His scientific publications were always held in high esteem; but his numerous contributions to lighter literature through the periodical press were perhaps still more calculated to raise a reputation. As reviewer, critic, epigrammatist, and author of witty and comic papers, he had few superiors; and his extensive knowledge of the world, and what is called life, gave him a ready hand for almost every subject. In society he was equally entertaining, and full of anecdote.'

Before we get to the sample anecdote that follows and links him to our second subject - Dr William Kitchiner - we shall look briefly at Haslam's achievements as a psychiatrist and pathologist. They were too technical to expound to the readers of the Literary Gazette, while the circumstances of his dismissal from Bethlem proved too damaging for the late doctor's reputation: the Bethlem "malpractice" scandal was not mentioned here nor by some modern writers.

The claim that Haslam was the first to describe the changes affecting the structure of the nervous system in patients suffering from a mental disease, specifically general paresis, is in essence based on a single case history and autopsy report. It appears in his only major book, first published in 1798 as Observations on insanity, revised in 1809 as Observations on madness and melancholy: including practical remarks on those diseases; together with cases: an account of the morbid appearance on dissection.

Haslam's Case XV was a forty-two-year-old servant, who became quarrelsome and developed ideas of grandeur, followed by marked dementia, dysarthria, paralysis of face and legs, skin ulcerations, anorexia, wasting, finally death..$^{8}$ In his way, Haslam described inflammatory meningeal changes and cerebral atrophy but said Case XV was one of those paralytic affections "independent" of their insanity (p. 260). Lucidly, he pointed out that they were "in general not at all sensible of being so affected .... It is fortunate for the condition of the sufferer that his pride and pretensions are usually exalted in proportion to the degradation of the calamity which afflicts him." Their incidence has been underrated. Paralyses, "are also a very common effect of madness" he added - an ambivalent attribution of cause and effect for many decades to come. For the second edition of this work (1809) he had had time to evaluate Pinel's "moral management" (published in his Traité médico-philosophique sur l'aliénation mentale, ou la manie, Paris 1801, translated as $A$ treatise on insanity in 1806) - and found it unsuccessful.

Why then was this on the whole sensible and sensitive man sacked?

In contrast to France, where the liberation of man from his "chains" of traditional and hereditary authority led to an explosion in the political set-up while an academic Dr Pinel - achieved a sensational if limited asylum reform, it was a lay group of religious activists in England - the Quakers - who aroused the public and Parliament to stop the inhumanity perpetrated on the insane. In those same 1790s, grandfather

${ }^{7}$ Loc. cit., note 5 above.

J. Haslam, Observations on madness and melancholy, London, Callow, 1809, pp. 115-118. 


\section{Haslam of "Bedlam", Kitchiner of the "Oracles"}

William Tuke of York founded that institution where the fear of God - his punishment through a troubled conscience - was to replace its physical equivalent. Intended for members of the Society of Friends, the Retreat was the reassuring English version of the forbidding Greek term asylum. Two decades later, in 1815, overwhelmed by public sentiment, greatly enhanced by news of their own sovereign's - George III periodic madness, the House of Commons decided to conduct an inquiry into madhouse practice, and their choice fell on Bethlem. Humanitarian as well as romantic stirrings, guided or goaded by the press, spread and energized the concern with the insane, perhaps more than with any other group of deprived fellow-beings.' The concern with this topic and its timeliness were reflected in the unprecedented output of books by English doctors dealing with insanity, as well as in fiction.

The methods used to restrain the insane aroused a horrified public. The Norris case, in particular, set all London agog, thanks to the newspapers and the man's engraved portrait, pitiful to behold in his harness and chains as it was exhibited in the "press shops".

Haslam's version - A letter to the Governors of Bethlem Hospital containing an account of their management of that institution for the last twenty years ... with a correct narration of the confinement of James Norris, by order of their subcommittee etc. - appeared two years after his dismissal. He claimed having proposed to confine Norris unshackled in two adjoining cells, and the occasional use of the strait-jacket. In preference to this "mild and humane contrivance", Norris was secured by an "iron apparatus", a frame constructed to encircle his trunk and upper arms, a collar chaining him to his bed, another chain fastened around his ankle to prevent him from kicking. In this contrivance, "better than a straight waistcoat", and "rather merciful and humane than rigorous and severe", Norris remained for ten years (June 1804 to May 1814) while, also according to Haslam, no complaints were heard from either the patient or the frequent visitors, including the Governors of the Institution. When the patient became so wasted that he could, Houdini-like, extricate himself from his "iron bondage", it was taken off on 17 May 1814, "on order of J. Haslam". Ten months later, Norris, who was an American-born sailor, died of consumption. Repeatedly quoting from the report by the Committee of Governors that no cruelty was involved, Haslam continued in his letter to them: "Surprisingly you did not publish [your report] until alluded to, a year later 5 October, 1815, during my first examination before the tribunal", i.e., when he was facing the Committee of the House of Commons. "You allowed judgement against you go by default, not only permitted but sanctioned, the discredit ... heaped upon you."10

That final judgment went, in fact, not against the Governors but only against Haslam and Dr John Monro, his immediate superior - scapegoats, it seems to me, for a whole system traditionally kept up by nearly all its representatives. To excuse the diehard professionals, those harassed purveyors "driven crazy" by their charges, we

${ }^{9}$ A. T. Scull, Museums of madness. The social organization of insanity in nineteenth-century England, London, Allen Lane, 1979; W. F. Bynum, 'Rationales for therapy in British psychiatry: 1780-1835', Med. Hist., 1974, 18: 317-334.

$10 \mathrm{~J}$. Haslam, A letter to the governors of Bethlem Hospital ... and interesting observations on the parliamentary proceedings, London, Taylor \& Hessey, 1818, pp. 2-30. 


\section{F. Schiller}

might invoke their constant and intimate exposure to accumulated unreason. It needs a degree of tolerance bordering on saintliness to maintain one's equanimity in close contact with the intensely irritating effect of insanity. Elsewhere, Haslam devoted several pages to the lowly keepers' plight, pointing out that "notwithstanding the occasional instance of misconduct ... intoxication, severity, or neglect ... their disadvantages ... personal hazard, scanty emoluments ... disqualified as they advance in years," keepers deserved more consideration, and he advocated their close co-operation with the physician in charge, in addition to the establishing of a pension fund for them. ${ }^{11}$ One cannot withhold applause for these suggestions nor sympathy with the bitter sarcasm he directed at his critics: "If the lunatics in Bethlem were not constantly drenched with medicine, it was inferred they were neglected; and when remedies were administered by the sanction of extensive and successful practice it was concluded that they were prescribed as punishment." 12 Had he not himself advocated "leniency"? He quoted from his book on insanity of 1798: "I can truly declare that by gentleness of manner and kindness of treatment, I have never failed to obtain the confidence ... of insane persons ... procuring ... respect and obedience. There are some ... not to be trusted ... [who] would always be kept under a certain restraint; but this is not incompatible with kindness and humanity."13 The italics are his. And had not a person unknown to him proposed that his health be drunk, at the traditional open air feast on St Georges's Fields? "It was the general opinion ... that I had acquitted myself with firmness and perspicacity." Alas, the Parliamentary Committee presumably took those for arrogance, rather, and slyness, and no "eulogy of friends" could alter the tribunal's shattering verdict. ${ }^{14}$

Middle-aged, the chastized apothecary and psychiatric expert found it hard to get on his feet again. He had to sell his admirable library of 1,167 volumes - science, poetry, travels, in several languages, complete with mahogany bookcase and stepladder. He made attempts to obtain a better degree, opened a private practice, and employed his sharp pen by contributing to lay periodicals, as well as to psychological literature. ${ }^{15}$

Nobody, perhaps to this day, could have satirized psychiatrists, in fact the whole medical profession, with more bite and gusto. Among Haslam's contributions to the Literary Gazette - anonymous by that weekly's tradition - are what we today would call a "column". Under the main heading "Sketches of Society", its title, "The Barley-Corn Club", in itself presents a jibe at the modish proliferation of clubs. This one is a fictional group of gentlemen, mostly retired from various pursuits and callings - possibly a forerunner of the Pickwick Club Dickens started thirteen years later. In "After-dinner Conversation at a Medical Party" the various specialists, despite their mutual sallies, agree that in order to prosper they must keep the public sick, preferably even make it become so, using such stratagems as spreading infectious diseases (as we call them). Of interest in our context are the exchanges with $\mathrm{Dr}$

" J. Haslam, Considerations on the moral management of insane persons, London, Hunter, 1817, pp. 34-38.

12 Haslam, op. cit., note 10 above, pp. 29-30.

${ }^{13}$ Haslam, op. cit., note 8 above, p. 21.

14 Haslam, op. cit., note 10 above, p. 16.

is Leigh, op. cit., note 2 above, p. 115. 


\section{Haslam of "Bedlam", Kitchiner of the "Oracles"}

Rantipole, the insanity physician. Asked his opinion by Sir Gingerbread Slumber who has paid for his knighthood and is appropriately baited by a Quaker colleague Rantipole refutes the suggestion that as a result of recent "specific action", insanity is "gradually assimilating itself to good sense." "I never dine with a party", Rantipole observes, "where there are not more lunatics than one constantly at table, the present company perhaps excepted." When Dr Stirabout, the apothecary, inquires about that famous "controlling power in thine eye to fascinate a furious madman into obedience and tranquility", Dr Cataract cannot refrain from interrupting: he deprecates this "vulgar error - ... it is like the department in which I practice - all my eye." In turn, Dr Dietbread wonders: "Would not the suppression of quackery by authority render the profession more honourable, and its legitimate members more opulent?" Rantipole demurs and remarks that "to a certain extent we all come under the denomination of empirics", adding that one has to keep up appearances, "the garb of mystery-decus et tutamen [dignity and defence] - Lay it aside, all decent people will avoid you." A Dr Placebo complains about his limited practice and admits to a habit of explaining to his patients the nature of their disease and the operation of his prescriptions. Deploring such counter-productive silliness, our psychiatric expert sounds quite modern:

It is my rule to look as wise as I can, and say as little as possible; indeed my reputation has been extended by imperturbable gravity and solemn silence. When a practitioner holds his tongue it is impossible to detect his ignorance; therefore in consultation I am inflexibly taciturn ... practitioners in other departments of course pursue a policy of their own. Pray, Ivory (turning to the Dentist,) how comes it that you have so much practice? Compared with your career of incessant occupation, mine, busy as it is, may almost be called a life of leisure.

Ivory. That circumstance naturally arises from the public taking more care of their teeth than of their understandings. Besides, my department of the profession is not merely scientific, but likewise ornamental. I can impart to the barren waste of an old mouth, disfigured by stumps, the regularity of Regent's Crescent; convert the tusk of a seahorse into a grinder; and so effectually supply organic defects of enunciation, that when any of my patients speak, the company present are filled with adoration at seeing a young head upon old shoulders. I have filed my way in the world.

Earlier in the proceedings Dr Diddleum has voiced the regret that:

Public confidence in our art has considerably abated; for the diffusion of medical knowledge has flattered the conceit and weakened the credulity indispensably necessary to every patient.

Dr Placebo. Allow me to hope that you are mistaken on this point, as all medical books (and I have published many) are supremely elevated above the comprehension of the public.

Dr Diddleum. That, Doctor, may be very true, but still these mischievous publications lead men to form their own opinions and prescribe for themselves, to the dereliction of professional advice. There is the rub: medical books are mere lures, hooks nicely baited for the sport and emolument of the author; and with respect to their contents, they are as unintelligible to the gentlemen of the faculty as to the public. ${ }^{16}$

Among other targets of Haslam's wit are: the anatomical nomenclature of the brain ${ }^{17}$ - all those "mothers", "stomachs", etc.; after-dinner speeches:

a heinous interpolation in the convivial converse of the evening; a loose, complicated, lengthy, tedious, intolerable parenthesis, the more intolerable because it is stuffed with meretricious common-places, and not infrequently garnished with scraps from the classic authors, misquoted, misapplied, and travestied into dog-latin, a tearful prelude to the deafening clatter of glasses on the table when the gentleman drops his anchor of 'thanks for the honour that has been done to him'.

${ }^{16}$ Lond. Lit. Gaz., 26 July 1823, p. 475; 16 August 1823, pp. 525-526.

17 Ibid., 13 September 1823, pp. 588-589. 


\section{F. Schiller}

Among "Hobby-horses", he decries "the projector, or system-monger, who takes credit for a larger share of common sense than is distributed among the rest of mankind."18 Other bores are punsters, linguistic pedants, vegetarians, and defenders of the vitality principle. Finally, poets: poets who have passed their prime, "sung themselves to sleep", poets with their maudlin and endless twaddle about the Elizabethan age, "bards becoming critics and politicians". Why not get rid of them by making them ambassadors? $\mathrm{Mr}$ Coleridge, "pulchrified, perfumed ... and raised to the peerage ... Baron Coleridge should be sent in a frigate to St. Petersburg ... Wordsworth [once an agnostic, now writing Ecclesiastical sonnets] ... to the Pope as Cardinal W .... Mr Southey [who had recently completed a History of Brazil, 1810-1819] ... minister plenipotentiary to Spain, Portugal and the Indies ... to reconcile differences between mother country and colonies ... Sir Walter Scott to Vienna ... to calm the Emperor Francis's horror of revolution by the harmless and easy experiment of regenerating the literature of Germany ... [and finally] Lord Byron [for his advocacy of Greece liberated from the Turkish yoke] ... to the Sultan ...."19 The absence from this list of Shelley and Keats was due to their fairly recent demise, if not for reasons of genuine esteem; also, there are no references to famous essayist competitors, the literary flower of the age: Hunt, Hazlitt, Lamb, De Quincey. Middle-aged and in sympathy with a bygone age of reason, Haslam was out of tune with the romantic early nineteenth-century avant-garde.

Now as to the anecdotes, referred to in his obituary, the Literary Gazette told the one that linked Haslam to a London character far better known to its readers than he was himself. Described as his "most intimate friend", and by several years his junior, Dr William Kitchiner (1775?-1827) had been dead seventeen years by then. Kitchiner's Glasgow degree had not qualified him to practise in London, but he happened to be independently wealthy and never at a loss for worthwhile projects. "His medicating was book-making and his book-making was medicating", wrote William Jerdan, the Literary Gazette's chief editor, reminiscing decades later in a collection of contemporary profiles: "He was a great optician, a great musician, and a great gastronome." 20 Mainly the latter: "a notable fork", Charles Lamb called Kitchiner in one of his letters. ${ }^{21}$ To this day, connoisseurs of cookbooks are much amused and stimulated by his chef d'oeuvre, The cook's oracle. (Kitchiner's name and spelling, incidentally, appropriate enough in itself, must, of course, not be confused with Lord Kitchener (1850-1916), of Sudan, Boer War, and World War I fame although Jerdan and others have managed to misspell the gastronome.) E. Quayle's Old cookbooks (1978) devotes fourteen pages to the doctor. ${ }^{22}$ In California today, M. F. K. Fisher still finds the "English eccentric if ever there was one" important in her own "search for a correction in a recipe's anatomy." She confirms Kitchiner's claim of having revolutionized culinary literature. Using his phrase, she credits him with

\footnotetext{
18 Ibid., 23 August 1823, pp. 542-543.

19 Ibid., 30 August 1823, pp. 557-558.

20 W. Jerdan, Men I have known, London, Routledge, 1866, pp. 282-287.

${ }^{21}$ C. Lamb, Letters, edited by E. V. Lucas, New Haven, Conn., Yale University Press, 1935, vol. 3, p. 99.

${ }^{22}$ E. Quayle, Old cookbooks. An illustrated history, New York, Dutton, 1978, pp. 149-163.
} 


\section{THE \\ COOK'S ORACLE;}

CONTAININE

\section{RECEIPTS FOR PLAIN COOKERY}

ON THB

MOST RCONOMICAL PLAN FOR PRIVATE FAMILIES:

A L so

THE ART OF COMPOSING THE MOST SIMPLE AND

MOST HIUHLY FINISHED

ZBrotbs, Crabies, Soups, Zauces, Store Sautes,

AND FLAVOURING ESSENCES :

PASTRY, PRESERVES, PUDDINGS, PICKLES, \&c.

CONTAINING ALSO

A COMPLETE SYSTEM OF COOKERY

FOR CATHOLIC FAMILIES.

The Quntity of each Article is

ACCURATELY STATED BY WEIGHT AND MEASURE;

BEING THE RESULT OF

. Actual Experiments

INSTITUTED IN THE KITCHEN OF

WILLIAM KITCHINER, M.D.

$$
\text { A truon or }
$$

THE ART OF TVIGORATING WIFE BY FOOD

THE HOESEKEEPKR'S LEDEKR ;

THE ECONOMY OF THL EYES, AND EULKS POR CHOOSINO

AND USING SPWCTACLKS, OFERA CLAKSES, AND

TELKSCOPBS: ORSERYATION: ON SINGNG, RC., AND

EDTOR OF TAS NATIONAK, AND

SEA SONGS OF ENGLAND.

"Miscuit utile dulci,"

A NEW EDITION.

LONDON :

PRINTED FOR CADELL AND CO. EDINBURGH; SIMPKIN AND MARSHALL, AND G. B. WHITTAKER, LONDON; AND JOHN CUMMING, DUBLIN.

To be had of all Booksellers.

1827. 


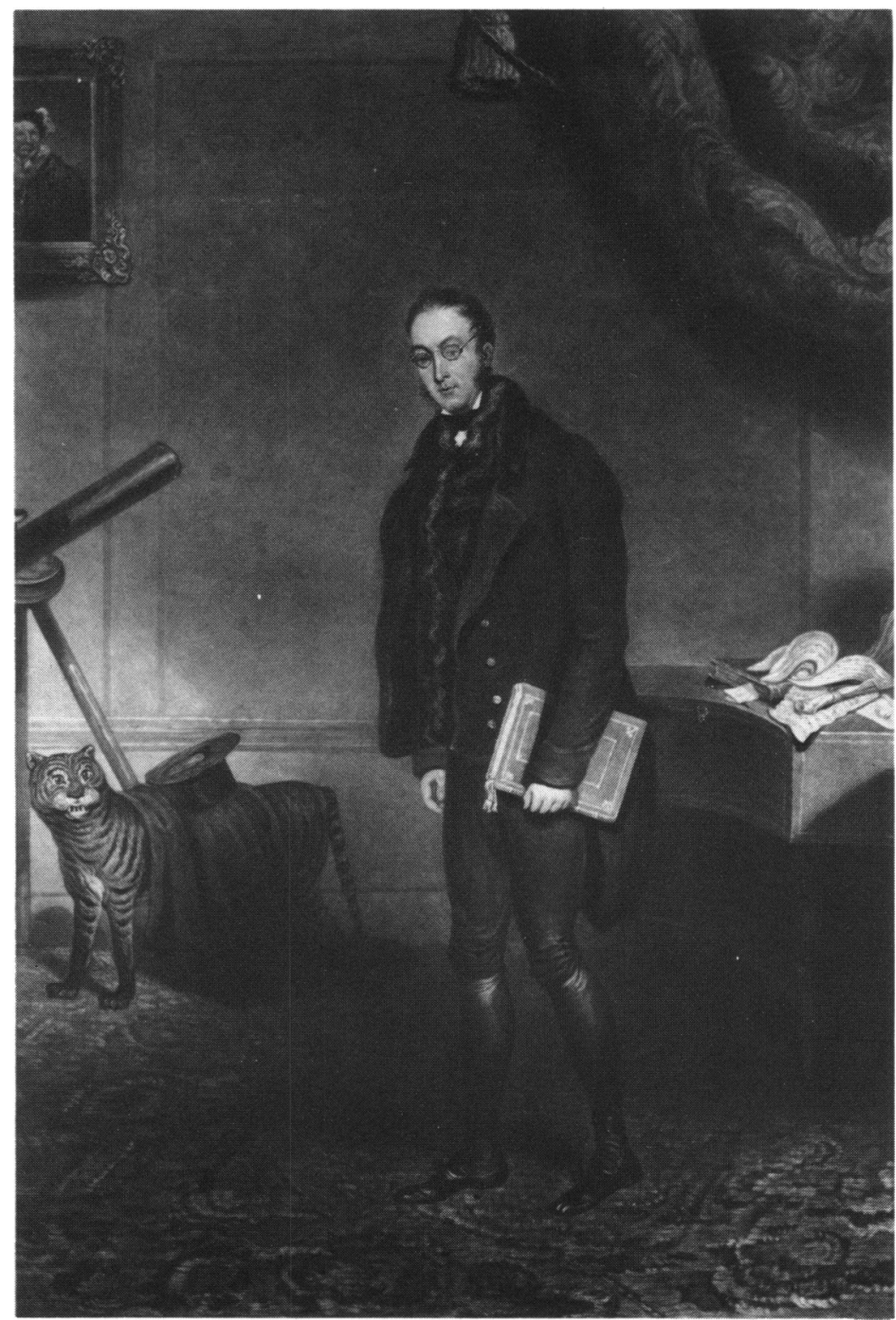

Figure 2. Portrait of Dr William Kitchiner (1775?-1827). Mezzotint by Charles Turner after his own design. Wellcome Institute library, London. 


\section{Haslam of "Bedlam", Kitchiner of the "Oracles"}

having said "farewell to 'the rule of thumb' in cookery and given exact measurements for every ingredient of a dish, as well as the order of their use." ${ }^{23}$ According to her, Mrs Isabella Beeton's Book of household management, prominent among the flood of Victorian books on the subject, owed a lot to this physician-gastronome, whose best friend, we might add, was an apothecary. The title, very full indeed, includes no vain promises nor does it lack information about the author's other works (Fig. 1).

To start with, no doubt must be left in the reader's mind that the most frequent cause of impaired health is poor food, i.e., the "injudicious manner in which it is prepared." Dogs and horses, the doctor also says in his Preface, receive twice as much attention by their [English] owners. Agriculture and the breed of cattle have been fostered at the expense of COOKERY! He then acknowledges the assistance of Henry Osborne, a chef in the service of Sir Joseph Banks, the famous botanist and late President of the Royal Society. Furthermore, Kitchiner refers to the information gathered by having "patiently pioneered through ... upwards of TWO HUNDRED COOKERY BOOKS" 24 A pioneer indeed, he may have originated the bottling of store sauces although, also according to Quayle, canning of food was perhaps invented a little earlier, in 1810, by a M. Appert of Paris. To Kitchiner's talents as inventor, one must add those in the business of advertising. One of his bottled appetizers was ZEST, "Doctor Kitchiner's Magazine [store] of Taste":

\section{ZEST \\ Will add life to your \\ chops, sauces and made dishes!}

This piquant quintessence of Ragout imparts to whatever it touches the most delicious Relish ever imagined! It awakens the Palate with Delight, refreshes the Appetite, and instantly excites the good humour of every Man's master - the Stomach.

And he repeats:

ZEST has a hundred uses. With two Drachms of ZEST in half a pint of melted butter you have a quickmade Savoury Sauce! Let it boil up and strain it through a sieve before serving. Or, each guest may add it, at table, like Salt, and so adjust the vibrations of his Palate to suit his own fancy.

ZEST could be obtained both at his home address and at "Butler's Herb Shop, opposite Henrietta Street, Covent Garden; where may also be had The Cook's Oracle."

The Oracle's first edition in 1817, preceding Brillat-Savarin's Physiologie du goût by eight years, is in its title preceded by Apicius Redivivus. Apicius was the legendary gourmet under Tiberius, who allegedly committed suicide when left with a paltry $£ 80,000$ (Edwardian), inadequate to cater for his and his friends' exquisite palates; until then he had spent ten times as much on their satisfaction. Hence also Apicius de re coquinaria: in 1498, this presumably was the first cookbook in print. ${ }^{25}$ Socialminded, Kitchiner's own intentions are "to bring the enjoyment and indulgences of the Opulent within reach of the middle Ranks of Society ... that the most inexperienced student in the occult Art of Cookery may work from my recipes with the utmost facility ... those who never shook hands with a Stewpan ... blend the toothsome with the wholesome." But "to enjoy and digest well" one must "purger souvent", a maxim

${ }^{23}$ M. F. K. Fisher, With bold knife and fork, New York, Putnam's Sons, 1968, p. 18.

${ }^{24}$ W. Kitchiner, The cook's oracle [1817], London, Edinburgh, Cadell, 7th ed., 1827, pp. I-XV, 1-23.

${ }^{25}$ Quayle, op. cit., note 22 above, pp. 10-11. 


\section{F. Schiller}

taken from the Almanach des gourmands. Hence Kitchiner reinforces his own Peptic precepts (a book he published in 1821) by Peristaltic Persuaders - pills composed of powdered Turkey rhubarb, syrup, and a touch of oil of caraway. To hundreds of precise recipes he has added a Housekeeper's Ledger, "that a young lady may learn the delectable Arcana of Domestic Affairs, in as little time as is usually devoted to directing the position of her hands on a Pianoforte, or her feet in a Quadrille - this will enable her to make the Cage of Matrimony as comfortable as the Net of Courtship was charming." 26

These samples of florid and somewhat stilted writing fit the style of the man "than whom", recorded his obituarist, "perhaps, there was not an individual in our populous city more generally known." As to his cooking, "it was not always easy to tell, in partaking of what was set before you, whether you might be swallowing a meal or a prescription at his hospitable, or, as the case might be, his hospital board." The gastronomic teacher's "tureen of soup was not liked the better for having its ingredients explained, and the price - perhaps sixpence or sevenpence - recorded." The wines too, of all ages, lent themselves, of course, to connoisseurish comments, some old ones, for instance, "having eaten up their crust." A weekly institution, his dinner parties were given for a "Committee of Taste": six to eight intimates of repute, and if "by no means so bizarre as rumour gave them out ... they were strictly timed by means of a sign posted in the hall saying "Come at seven: go at eleven". (A wit - was it Haslam? at one time inserted "to it" after "go" - a roaring success lasting into the wee hours. ${ }^{27}$ These dinners were supplemented by Tuesday night "conversaziones", also enlivened by the famous comedian and character actor John Kemble (1775-1854). "In general very silent and timid in his manner", Kitchiner nevertheless was apt to indulge in inventing funny neologisms to christen funny things such as calling an elaborate brew, his conception of a night cap, Tewahdiddle. There even existed a "Tewahdiddle Club of Authors and Publishers", as we learn from an advertisement in the Literary Gazette for a monthly called "The Family Oracle of Health, Economy, and Good Living". The authors of the Family Oracle are given as a Dr Crell and a Mr Wallace. Among the other titles included in that Nr. XI are such undying items as "Nervous indigestion, Low spirits, and Face Flushings", "Philosophy of bathing and electricity", "Effects of training on the blood and lungs", "Milk diet in the cure of declines" [wasting away, eighteenth century], "Causes and remedies of freckles", and "Humbug of French tonic wine". ${ }^{28}$ The authors of History of five centuries of English diet have no doubt that Kitchiner was "one of the leading lights of the Committee ("of Scientific Gentlemen') who edited The Family Oracle of Health." Their frontispiece, a cartoon of the period, shows him as the central figure gobbling up illegal living oysters. In their opinion, the compendium is "a mine of amusing and instructive information", from which they quote the daily ordinary people's (artisan class) consumption: "Bread $\div-1 \mathrm{lb}$; Meat $\frac{3}{4}-1 \frac{1}{1 b}$; Vegetables $\frac{3}{4} \mathrm{lb}$; Butter $\frac{1}{2}-1 \mathrm{lb}$; Beer $1 \mathrm{pt}$ to $1 \mathrm{qt}$." They rightly assume that the higher figures for meat and butter are an overestimate,

\footnotetext{
26 Kitchiner, loc. cit., note 24 above.

${ }^{27}$ Lond. Lit. Gaz., 3 March 1827, pp. 139-140, and Jerden, op. cit., note 20 above.

24 Lond. Lit. Gaz., 5 June 1824, p. 367.
} 


\section{Haslam of "Bedlam", Kitchiner of the "Oracles"}

given the fact that one pound of butter alone yields 3,500 calories. ${ }^{29}$

Thomas Hood (1799-1845), the poet, sensitive to the plight of the poor, also a master of punning, doggerel, and caricature drawing, acclaimed Kitchiner as "the most heterogeneous of Authors, but at the same time ... a real Homo-genius, or a Genius of a Man!" Hood ascribes to Kitchiner the authorship of the following poem in his honour: "A recipe - for civilization". It makes the point that cooking distinguishes man from the beasts, and the civilized from the primitive, in such lines as:

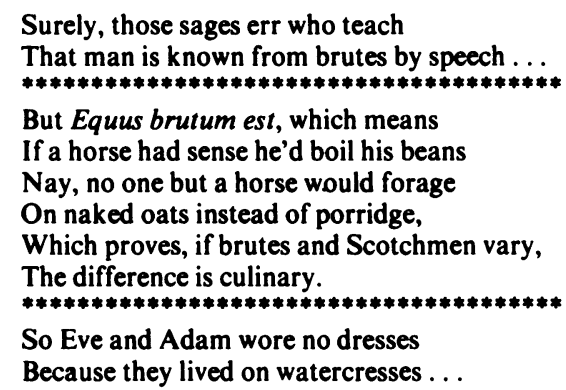

All this is graced by a cartoon depicting The cook's oracle with a frying-pan for a head and presenting musical notes on a trivet for a stave..$^{30}$

Kitchiner indulged in composing, performing, and supporting popular music. For $\mathfrak{6 0 0}$, he commissioned Charles Dibdin (1745-1814), the well-known actor, dramatist, and, above all, composer of sailors' songs, to contribute a dozen such for "La Belle Assemblée", as the "Committee of Taste" was also called. He duly added a short biography (1832) to Dibdin's own four-volume autobiography (1803). Not for nothing does Kitchiner receive nearly a whole column up to the fifth, if not the new, edition of Grove's Dictionary of music, which also records an early operetta of his: Love among the roses, or The master key. ${ }^{31}$ The doctor as host often accompanied himself to songs of his own creation. These make up another one of his books; more grace his posthumously published Traveller's oracle, ${ }^{32}$ again a mixture of instructions all at once practical, chatty, and outlandish.

Describing Kitchiner's appearance, Jerdan's phrase "his square-toe cut of habiliments" does not clearly stand for either old-fashioned elegance or dowdiness; perhaps it was a peculiar combination of both. His character is summed up as "exceedingly good-natured withal. Though occasionally petulant, he speedily forgave offence, and refraternized with the offender." ${ }^{33}$

Kitchiner's infrequent petulance, however, did not subside so speedily in at least one instance. This is the subject of the aforementioned anecdote. It tells how, on one occasion Haslam, somewhat sadistically, kept stoking the fire of his friend's fury. "We

29 J. C. Drummond, and A. Wilbraham, The Englishman's food. A history of five centuries of English diet, London, Cape, 1939, pp. 395-397.

${ }^{30} \mathrm{Th}$. Hood, Whims and oddities in prose and verse; with forty original designs, London, Lupton Relfe, 1826, pp. 14-17.

${ }^{31} \mathrm{G}$. Grove, $A$ dictionary of music and musicians, London, Macmillan, 1877-1900.

${ }^{32} \mathrm{~W}$. Kitchiner, The traveller's oracle, or maxims for locomotion ... hints for preserving the health ... estimates of the expenses... with seven songs, London, Colburn, 2 nd ed., 1827.

${ }^{33}$ Jerdan, loc. cit., note 20 above. 


\section{F. Schiller}

remember", says Haslam's obituarist (Jerdan):

During a temporary absence from town, [of the journal's regular reviewer] that he wrote a review, which was inserted in the Literary Gazette, on one of Dr Kitchener's books. It was very droll and humorous, and laughed good-naturedly enough at some of the worthy doctor's eccentricities. But the doctor took it in the dungeon [sic; a printing error, presumably]; and in an extreme rage happened to pitch on his friend Haslam to consult what steps he would advise him to take against the worthless libeller! This was fun to Haslam, and he abused the writer and the Gazette to the topmost of Billingsgate till he inflamed Kitchiner beyond all mitigation. ${ }^{34}$

The book of his friend which Haslam reviewed had several famous predecessors such as André Tissot's Avis au peuple sur la santé ("Health information for everybody") of 1760 and Christian Hufeland's Makrobiotic of 1797, and many have been written ever since. It bore the title The art of invigorating and prolonging life by food, clothes, air, exercise, wine, sleep, etc., and gave as the author The cook's oracle - Kitchiner's popular trade- and nickname. It is, Haslam started to say, "not only from the admirable contrivance of certain pills, called 'Peristaltic Persuaders,' that the learned doctor has derived his reputation." There is his "profound work on telescopes, spectacles, and panoptician eye-tubes ... [by means of which] the purblind are immediately brought into the society of the remotest stars", which, to quote Kitchiner's own words, "appear clean-shaved" as a result. Also "a celebrated musician", he had "originally an extremely delicate constitution", but through "the study of Physik" he was "learning to make the most of his small stock of health." Haslam does not fail to add his devilish little put-down: "If all the puny children in this country were brought up to the study of physic, it might conduce to beneficial results, both to themselves and the community; or it might not." "Contents of the several chapters", he remarks, "do not correspond to titles; but this trifling informality introduces greater variety .... Under 'Siesta' we have directions to encourage dram-drinking [tippling] in vocal performers, in order to dispel mauvaise honte [?timidity, stage fright], and eradicate nervous trepidations; and the philosophical reason assigned (p. 98) is, that 'to wet your whistle is as absolutely necessary as to rosin you bow'.... An important subject, on which most literary persons, when they can get it, are disposed to dwell - WINE ... He endeavours to establish 'that the true economy of drinking is to create as much exhilaration as may be with as little wine.' To us this appears to be the art of prolonging, not life, but wine." The reviewer is taken aback by Kitchiner's advice of mixing and diluting spirits, making them ever stronger as you go along with and after your repast, to lie down finally and sleep for half an hour. Specially appalling is this attitude: “... à la cochon the doctor drinks by instinct to the total abandonment of that reason which is the attribute of his species - perhaps he will next time try to persuade us that he writes by instinct." His concluding lines: "We now take a friendly leave of the doctor, his unwearied labors and tidbits, fully persuaded that his rules of the prolongation of life will confirm the aphorism, - Ars longa, vita brevis." ${ }^{35}$

Anonymous, condescending, and ridiculing a somewhat foolish friend, was this review, as Jerdan, the editor, put it, just the work of "an astute and yet lively writer, with a vein of good-humoured satire, which tickled every body and hurt nobody"? ${ }^{36}$

34 Loc. cit., note 5 above.

${ }^{35}$ Lond. Lit. Gaz., 8 September 1821, pp. 561-562.

${ }^{36}$ W. Jerdan, An autobiography, London, Hall, Virtue, 1853, vol. 3, p. 279. 


\section{Haslam of "Bedlam", Kitchiner of the "Oracles"}

Or, as the butt of a "droll and humorous" mockery, yet such as to border on nastiness, was Kitchiner not entitled to feeling hurt rather than tickled? Are we in some way today more thin-skinned than were readers of over 150 years ago when we sympathize with the victim, or even experience a certain revulsion, rather than mere mirth, at this anecdote? Only his alibi of having been out of town when the review appeared, says Jerdan, "pretty well restored me to the whimsical doctor's good graces... Unable, in honour, to give up the writer, I had to bear the brunt of the fiercest resentment, and it was only by the interference of mutual friends that I was again admitted into Kitchiner's chosen circle, from which it was a real vexation to be banished." Reading to "the astonished writer paragraph by paragraph" and putting to him "earnestly, such passages as to be too bad to be endured - in all which Haslam entirely concurred - ... [Kitchiner] came to the conclusion that he thought he ought to call me out [to a duel], which the said Haslam expressed his opinion must be the only step he could or ought to take." 37

Not content with this reaction - hilarious to him and the editor - Haslam was ready and anxious for dealing a second, now unsolicited, blow to his friend. Milder in tone, if still strongly satirical and unmistakably directed against the Oracle, there appeared two weeks later in the Gazette another article from Haslam's anonymous pen: "Unpalatable Recollections. Selected from the private memoranda of a distinguished epicure." The mention of "peristaltic persuaders" filling a gold pill-box sitting on the dining table, as well as many other allusions, clearly identified the token "autobiographer" of this piece. A bachelor, we read [Kitchiner was in fact divorced after a brief marriage and had an illegitimate son], ${ }^{38}$ partly by choice and partly by his unattractive corpulence, "he" went on to tell of his self-absorption and contempt for politics and public life. Next, he discovered for himself a solemn mission in this world: "To invent new dishes, and devour them." Hence the emended Popian line: "The proper study of mankind is FOOD." After making his apprenticeship by reading the culinary literature of the ages, he visited "the better sort of coffee-houses and taverns" and noisy clubs, to arrive at founding, in a sumptuous setting, his somewhat different, quiet, dignified own. The company's gastronomic ecstasies demanded an ambience which included what we would call air-conditioning:

I control climate in the dog-days ... in hot weather my dining room is artificially cooled. Twelve large copper vases, painted to resemble china, are placed in the apartment, filled with ice and salt - by this admirable contrivance, when the temperature is at 82 , I can sink the thermometer down to 50. Many persons who have dined with me at these Arctic meetings, for the first time, have exclaimed: 'what a prodigious change in the weather! We shall have but a short summer!' Some have taken a bumper of brandy to keep the blood in circulation; and one gentleman whispered my servant to bring his great coat. ${ }^{39}$

This renewed attack, according to Jerdan, "incensed the Cook's Oracle to the utmost height of red culinary heat ... I firmly believe my mischievous critic was distressed that he had to wait a fortnight before he could fire his second shot." 40

To have only these facts, together with a third person's - Jerdan's - comments, does

${ }^{37}$ Ibid, p. 280.

${ }^{38}$ Quayle, loc. cit., note 22 above.

${ }^{39}$ Lond. Lit. Gaz., 22 September 1821, pp. 604-605.

${ }^{40}$ Jerdan, loc. cit., note 36 above. 


\section{F. Schiller}

not make it easy for us to form an entirely independent opinion about our two protagonists and their relationship. But must not psychobiographical interpretations, at best, always remain open to some doubt? In any case, we could hardly fail to share Jerdan's observation: Haslam, he explains was "himself an original, and with a tinge of that eccentricity which seems frequently to have accrued from scientific devotedness to the medical treatment of insanity, and mingling much with insane patients ...." 41 Either this or the reverse, i.e., a native eccentricity causing scientific devotedness to the phenomenon of insanity, may have been the mainspring for Haslam's attachment to the eccentric Kitchiner: a subject for study, experiment, and, partly, also identification. Does Jerdan's generalization, straight or reversed, perhaps fit a basic trend in psychiatrists of any period? Writing some thirty years after the event, Jerdan is careful to add a mitigating footnote:

I have rejoicingly written this in the past tense, because I have witnessed, since the feeling and humane system has been introduced, and I trust generally adopted, the aberrations of the afflicted have not the same tendency to affect the minds of those who are charged with the most trying and interesting of all human trusts, the care of them, and the device of means to restore them to their sorrowing friends. ${ }^{42}$

This involved statement may strike us as over-optimistic. It implies that the current asylum reform, "the feeling and humane system", had reversed a previous vicious cycle and turned it into its beneficial opposite: the humane treatment of the insane now improving both their minds and, in turn, also those of their keepers.

Like any satirist, Haslam was half in love with his subject, paradoxically building up what he meant to pull down. To be the target of satire or caricature can therefore be advantageous by virtue of underlining the absurd person's popularity. Left-handed compliments in reverse, caricatures have increasingly become a kind of publicity where the person, far from being odious, is depicted or described for the endearing humorous effect of his or her oddity. Caricatures, pictorial and verbal, were mushrooming - no less than clubs, periodicals, and essays, together with the population, i.e., readers, writers, and artists - ever since the late eighteenth century. But initially that ambiguous secondary derivation, the positive or favourable aspect of the art, was as yet little realized. It would perhaps have been asking too much of the victim to share in the fun, show a sense of humour, and even feel flattered by the heightened attention he was getting. Sensibilities change with the times, the fashions. But, in fact, that friend's - or enemy's - comic blasts do not seem to have hurt the sale of Kitchiner's books or his image with the public, or dampened his enthusiasm for writing more, in that idiosyncratic, unintentionally funny vein of his. As for Haslam, to keep the wolf from the door, he had to do what he knew best: exercise his skill with titillating words, and his critical spirit. He never could stop being preoccupied with the follies of his fellow-men while displaying a minimum of regard for their innocent susceptibilities, and the niceties, not to say the ethics, of friendship. At any rate we cannot very well regard Haslam's bringing to a boil his friend's hot anger as intentional or sound treatment: a forced "abreaction" as it were. Trying to calm him down, on the other hand, might have been a psychotherapeutic mistake and ineffective to boot.

41 Ibid.

42 Ibid. 


\section{Haslam of "Bedlam", Kitchiner of the "Oracles"}

Unfortunately, Haslam was not only one of the old school of psychiatry turned satirist. In our minds, he also cannot be entirely absolved of having performed an inhumane experiment on a friend, quite likely to satisfy his own curiosity or, worse, giving in to a sadistic bent. Again, Jerdan apparently saw nothing reprehensible in this. As the editor of a magazine, he would have welcomed the comic appeal to his customers, taking his own discomfiture in the bargain. Hence, he gave free rein to a contributor whom he appreciated as "a great gun for several years", also "very droll and entertaining in society." 43

Recalling the last evening of Haslam's life, "the most cordial we spent in his company from the day of the Libel", Jerdan, counting himself as the second victim, concludes: "Many a laugh had Haslam at our cost when he could tell us of some entertaining symposium with the Cook's Oracle, from which we were excluded on account of his banter and amicable advice to the offended author. Our readers may see that there are occasionally merry humours among the labours of the press." 44 Words, it may seem, somewhat surprising for concluding an obituary.

Some of the rough light-heartedness current in the Georgian era was passing, however: by 1844, Queen Victoria was into the eighth year of her long solemn reign, marking, among other things, the decline of English cooking. But many readers of the Gazette must have remembered the endearing $\mathrm{Dr}$ Kitchiner, and some of his insufficiently heeded precepts, a figure and a writer, helpful and sound, entertaining as well as pedantic, learned, and not a little ridiculous. Luckily, perhaps, he had been spared the shock of having to identify one of his best friends with one of his worst tormenters to the very day that ended his life - short enough at fifty-two to belie his belief that he had the instinct and know-how of prolonging it and so benefit his many readers. That his trust in Haslam was never disappointed speaks, after all, for the latter's human qualities as well.

${ }^{43}$ Ibid.

${ }^{44}$ Loc. cit., note 5 above. 